DOI: 10.20472/IAC.2018.044.056

\title{
BORUT ZGONC
}

University of Ljubljana, Faculty of Economics, Slovenia

METKA TEKAVČıČ

University of Ljubljana, Faculty of Economics, Slovenia

MARKO JAKŠIČ

University of Ljubljana, Faculty of Economics, Slovenia

\section{INTERNALIZATION OF EXTERNAL COSTS AND ITS IMPACT ON MODAL SPLIT IN THE FREIGHT TRANSPORT MARKET}

\begin{abstract}
:
The purpose of this research is to examine the impact of internalization of external costs on modal split in the freight transport market. It is expected that the internalization of transport externalities will contribute to the redistribution of freight volumes in favor of non-road transport modes, especially railway. To answer this expectation, the break-even distances between intermodal rail-road and unimodal road are calculated. The calculation is based on the costs, as the most important factor that influences the mode choice in the freight transport market. In order to establish as general as possible a model, independent of a certain transport corridors, the model relies on a Monte Carlo simulation that takes account of a randomly generated shipper and receiver's locations in two separated market areas. The model consists of a submodule for calculating drayage distances and costs in a circular market area and another submodule for calculating the distances and costs between two separated market areas, taking different distance metrics into account. The results confirm the importance of internalization of external costs on the mode choice and its contribution to the more sustainable transport system. Additionally, the results show there is not only one but, in fact, many break-even distances between the two modes. They vary considerably depending on different travel plans, and shipper/receiver locations within market areas. Despite the inevitable assumptions made in such general analysis, the results reveal that intermodal rail-road transport can provide a good alternative to unimodal road transport, even over relatively very short distances if the drayage costs are not too high and if external cost of transport are included in the price of all transport modes.

We believe the research helps better understand competitiveness in the freight transport sector and may also be useful for policy- and other decision-makers to decide the priority of policy options, such as providing subsidies to stimulate intermodal rail-road transport. Increasing truck rates, e.g., by adding taxes, has been found to be effective policy to increase the intermodal rail-road mode share.
\end{abstract}

\section{Keywords:}

Freight mode choice; Break-even distance; Intermodal rail-road transport; External costs; Monte Carlo simulation.

JEL Classification: L91, R40 